\title{
STREAM MACROINVERTEBRATES AND HABITAT BELOW AND ABOVE TWO WILDERNESS FORDS USED BY MULES, HORSES, AND HIKERS IN YOSEMITE NATIONAL PARK
}

\author{
Jeffrey G. Holmquist ${ }^{1,3}$, Jutta Schmidt-Gengenbach ${ }^{1}$, and James W. Roche ${ }^{2}$
}

ABstract.-Wilderness stream crossings used by mules, horses, and hikers are localized disturbances that may affect habitat immediately downstream, but the potential influence of fords on streams has received little investigation, particularly in terms of possible effects on fauna. Our overall null hypothesis was absence of below-above differences for either benthic macroinvertebrate assemblages or habitat characteristics at such fords. We further sought to determine (1) whether any such differences were present prior to annual use, suggesting longer-term effects, and (2) whether differences were present in late season, after annual use. We examined macroinvertebrates and habitat immediately below and above 2 fords crossing subalpine streams in Yosemite National Park in the Sierra Nevada (California, USA) in early and late season and over 2 years. There were both longer-term below-above differences, as well as differences that became apparent in late season, both of which were indicative of below-ford effects. Below fords there was evidence, either as main effects or interactions, of higher silt, sand, and gravel cover; a thicker periphyton layer; a greater Hilsenhoff biotic index; a higher proportion of tolerant taxa; higher chironomid midge and total densities; and greater species richness, largely a function of chironomid richness. There was also a lower expected number of species, a smaller proportion of sensitive taxa and predators, and lower densities of some sensitive Ephemeroptera (mayflies) and Plecoptera (stoneflies) below fords. Both hikers and stock may contribute to the apparent effects, but management interventions targeting stock may be particularly achievable. Among other approaches, simply halting stock strings briefly before reaching fords should reduce the volume of urine and feces directly entering streams, and handlers can expedite crossings if watering is not necessary.

RESUMEN.-Los senderos naturales utilizados por mulas, caballos y excursionistas para cruzar arroyos son perturbaciones localizadas que pueden afectar el hábitat rio abajo inmediatamente, pero la posible influencia de los vados en arroyos ha sido objeto de escasa investigación, particularmente en lo que se refiere a posibles efectos sobre la fauna. Nuestra hipótesis nula general fue la ausencia de diferencias, entre la superficie y el interior, de grupos de macro-invertebrados bentónicos o en las características del hábitat en esos vados. Además, intentamos determinar si (1) cualquiera de dichas diferencias estuvieron presentes antes del uso anual, lo cual sugeriría efectos a largo plazo, y/o (2) si las diferencias estaban presentes al final de la temporada, tras su uso anual. Examinamos los macro-invertebrados y el hábitat inmediatamente por debajo y por encima de 2 vados que cruzan arroyos subalpinos en el Parque Nacional de Yosemite, en Sierra Nevada, (California, EE.UU.) en temporada temprana y tardía durante casi 2 años. Encontramos diferencias a largo plazo tanto por debajo como por encima, así como diferencias que se hacen evidentes al final de la temporada, las cuales son indicadores de un cierto nivel de efectos bajo los vados. Bajo los vados había evidencia, tanto en efectos directos como interacciones, de: mayor cantidad de obstrucciones de sedimentos, arena y grava; una capa más gruesa de perifiton; un índice biótico Hilsenhoff más elevado; una mayor proporción de taxa tolerantes; más quironómidos y densidades totales y una mayor riqueza de especies, esto último debido en gran medida a una función de la riqueza de quironómidos. También encontramos un número más reducido de especies de lo esperado, menor proporción de taxa sensibles y depredadores, y densidades más bajas de algunos Ephemeropteras sensibles y Plecoptera bajo los vados. Tanto los excursionistas como el ganado podrían contribuir a los efectos aparentes, pero la aplicación de acciones de manejo referentes al ganado puede ser un objetivo particularmente alcanzable. Entre otros enfoques, el hecho de contener, por medio de las ataduras del ganado brevemente antes de alcanzar las veredas, reduciría el volumen de orina y heces que entran directamente en los arroyos, y los responsables podrían agilizar los cruces si no fuera necesario beber agua.

The balancing of stream conservation with human and livestock access is an almost universal management concern (Mathooko 2001, Newsome et al. 2004, McIver and McInnis 2007). Most related work has focused on disturbance distributed along one or more stream reaches (e.g., Braccia and Voshell 2007, Herbst et al. 2012). However, stream crossings on formal trails used by hikers and stock are localized disturbances focused at fords and habitat immediately downstream (Miller et al. 2010). Sedimentation can be higher at or below

\footnotetext{
${ }^{1}$ White Mountain Research Center, Institute of the Environment and Sustainability, University of California Los Angeles, Bishop, CA 93514

${ }^{2}$ Yosemite National Park, El Portal, CA 95318.

${ }^{3}$ E-mail: jholmquist@ucla.edu
} 
fords relative to above-ford habitat (Fritz et al. 1999, but see Miller et al. 2010) which may, in combination with input of urine and feces (Miller et al. 2010), affect aquatic fauna (Kidd et al. 2014). Investigation of effects of fords on fauna has been limited (Kidd et al. 2014); Fritz et al. (1999) found that effects of bison crossings on benthic invertebrates were minor and concentrated in the area directly traversed by the animals, but effects of bison fords likely differ from those of the more frequent crossings made by domestic livestock and hikers at trail crossings. Mountain streams may be particularly sensitive to disturbance, especially if late-season flows are further lowered by drought or water withdrawals (Holmquist and Waddle 2013, Waddle and Holmquist 2013, see also Mathooko 2001).

Hiking and transport by horses and mules are the primary modes of travel along trails in fragile wilderness areas, and the consequences of such use is an important issue for managers (Olive and Marion 2009, Pickering et al. 2010). Strings of equine stock (pack stock) used for day tours and supplying remote locations, particularly in the western United States (McClaran 1989), travel along trails, and stock often urinate and defecate directly into streams while the pack strings are stopped mid-stream for watering at trail fords (Derlet and Carlson 2006). Horses and mules are heavy animals and are further laden with people and supplies. Their steel-shoed hooves have a high mass per unit substrate contact area (Newsome et al. 2004). Resuspension of fines and particulate organics is thus a possible result of stream fording. Equines are known to disrupt soil integrity on trails to a much greater extent than hikers (Wilson and Seney 1994, Deluca et al. 1998), thus increasing input of nutrients and sediments to streams via sloped trail approaches to fords (Olive and Marion 2009, Kidd et al. 2014). Although hikers create fewer effects on a perindividual basis, there are more hikers than stock along trails (Törn et al. 2009). Humans and equines (Cole 1995, Cole et al. 2004, Holmquist et al. 2014, Ostoja et al. 2014) have generally, though not exclusively, negative effects on wetland vegetation and fauna. Similarly, there may be negative effects on stream macrofauna immediately downstream of fords, but it is also possible that limited increases in particulate organics, periphyton, and habitat heterogeneity could enhance diversity in these oligotrophic streams without negatively affecting sensitive taxa (Braccia and Voshell 2007).

Our overall null hypothesis was that there would be no below-above ford differences for benthic macroinvertebrate assemblages and habitat characteristics. We further sought to determine if there were interannual carryover effects that were present immediately below fords during early season (i.e., before new stock use or significant hiker use) in a given summer. Lastly, we wished to compare any such differences apparent during early season with conditions during late summer, after the majority of seasonal ford use. Such late-season sampling would capture both short-term annual effects as well as any interannual effects that might only become apparent later in the summer.

\section{Methods}

\section{Study Area, Design, and Sites}

The trails of the Sierra Nevada of California have been traveled by foot, horse, and mule for well over a century, particularly since the 1940s (McClaran 1989), so there is potential for both current and legacy effects of fording disturbance. Tuolumne Meadows, in Yosemite National Park, is a primary staging area for stock and hiker use throughout the short subalpine summer.

This study focused on habitat immediately below and above fords (Below, Above) using above-ford reaches as reference habitat (Stoddard et al. 2006). We sampled in early summer ("Early"; <1 week before stock use began and before most hiker use; mean day of sampling: 10 June, SE 5 d) and again in late summer ("Late"; 11 August, SE $14 \mathrm{~d}$ ), in 2 streams (Delaney and Ireland Creeks), and during 2 summers $(2012,2013)$; thus the design was a $2 \times 2 \times 2 \times 2$ balanced factorial design. The elements of greatest interest were (1) potential Treatment main effects across both early and late season, (2) Treatment $\times$ Season interactions that might indicate increased below-above differences after most annual use, as well as (3) Treatment $\times$ Stream interactions. We used stratified-random selection of sample locations from cobble-dominated riffle habitat that was no more than $80 \mathrm{~m}$ below or above a ford. There were 3 randomly selected sampling locations for each combination of factor levels, 
thus a total of 48 , and 3 new locations were selected below and above each ford on each visit (i.e., both early and late season in each of 2 years). The fords represent $<4 \mathrm{~m}$ of stream length, so "under-foot" effects are spatially limited (Fritz et al. 1999), and we thus examined potential effects immediately downstream.

Delaney and Ireland Creeks are secondorder, low-gradient $(<0.2 \%)$, subalpine streams dominated by riffles and separated by $7 \mathrm{~km}$ (Delaney Creek ford: $37^{\circ} 53^{\prime} 06^{\prime \prime} \mathrm{N}, 119^{\circ} 22^{\prime} 39^{\prime \prime} \mathrm{W}$, $2620 \mathrm{~m}$; Ireland Creek ford: $37^{\circ} 49^{\prime} 32^{\prime \prime} \mathrm{N}$, $\left.119^{\circ} 16^{\prime} 43^{\prime \prime} \mathrm{W}, 2717 \mathrm{~m}\right)$. The use of only 2 streams is a limitation of this study; these streams were the only 2 in the funding-targeted study area with a combination of substantial stock usage, adequate wetted width, annual persistence, presence of riffles, and similar habitat below and above fords. The history of usage of these crossings is a strength of the study, which approximated a long-term experiment via sampling below and above the long-used fords. Both streams are bordered by lodgepole pine (Pinus contorta Douglas ex Louden) forest and wet and dry meadow plant assemblages (Moore et al. 2013). Sierran subalpine streams have high spring flows and low discharge later in the summer (Waddle and Holmquist 2013). Mid-season discharges were similar for the 2 years at each stream: $0.035 \mathrm{~m}^{3} \cdot \mathrm{s}^{-1}$ for Delaney (National Park Service [NPS] data) and $0.040 \mathrm{~m}^{3} \cdot \mathrm{s}^{-1}$ for Ireland (personal observation). Submerged vascular plants were essentially absent from the streams. There were 4600 Delaney crossings by individual mules or horses in 2012 and 4877 in 2013, as well as $\sim 16,000$ hiker crossings in both years (unpublished NPS data from permits and from images recorded with Reconyx PC800 motionsensitive cameras). Ireland had $\sim 400$ stock and $\sim 8000$ hiker crossings in both 2012 and 2013 , although stock traffic was greater $(\sim 1000$ stock crossings) at this ford as recently as 2010. There were several pack string crossings per day at Delaney $(\bar{x}=8.4$, SE $0.6,2013$ NPS data) and several per week at Ireland, whereas there were several hiker crossings per hour at both streams. Number of animals per stock crossing ranged from 1 to $15(\bar{x}=6.5$, SE 0.10, 2013 NPS data for Delaney).

\section{Sampling}

We sampled macroinvertebrates with a standard $0.3 \times 0.3-\mathrm{m}$ Surber sampler (Hauer and
Resh 2007) and recorded data on habitat characteristics that were likely to influence fauna; periphyton and coarse particulate organic matter (CPOM), for instance, provide both habitat and food resources for aquatic invertebrates (Allan and Castillo 2007). Prior to disturbing the substrate within the sampler, we determined depth (4 equidistant measurements) and percent cover by substrate particle size (modified Wentworth scale; Appendix), and we exposed larger particles in order to measure percent embeddedness, all within the area defined by the sampler. After completing each Surber sample, we measured velocity at 0.6 depth (General Oceanics meter, Miami, FL) and temperature and made a rapid periphyton assessment (see also Stevenson and Rollins 2007). Presence or absence of periphyton cover and thickness of the periphyton layer were recorded at 5 equidistant points along a transect running across the wetted width of the stream and located $0.25 \mathrm{~m}$ upstream of each Surber sample location (3 transects below and above each ford on each visit). Instead of subsampling, we sorted all fauna from each sample and identified each organism either to genus and species or, more frequently, genus and morphospecies. We separated all CPOM from each Surber sample into small $\left(<1 \mathrm{~cm}^{2}\right)$ and large $\left(>1 \mathrm{~cm}^{2}\right)$ categories. Each component was dried at $80{ }^{\circ} \mathrm{C}$ for $24 \mathrm{~h}$ and weighed.

The below- and above-ford physical environments were similar, as indicated by measures that were unlikely to be affected by crossings (Appendix). Gravel (2-16 mm), sand $(0.1-2 \mathrm{~mm})$, and silt $(<0.1 \mathrm{~mm})$ had the potential to be affected by crossings and are reported in the results.

\section{Analysis}

Analyses were via $2 \times 2 \times 2 \times 2$ general linear models that included Treatment, Season, Stream, and Year main effects, as well as all 6 two-way interactions (SYSTAT 2007). Habitat response variables included percent silt, sand, gravel, and embeddedness; small and large CPOM mass; and periphyton cover and thickness. Faunal metrics included total and population densities, species and family richness, percent dominance by the most abundant species in each sample, proportional composition by functional feeding groups, percent Ephemeroptera-Plecoptera-Trichoptera (\%EPT), 

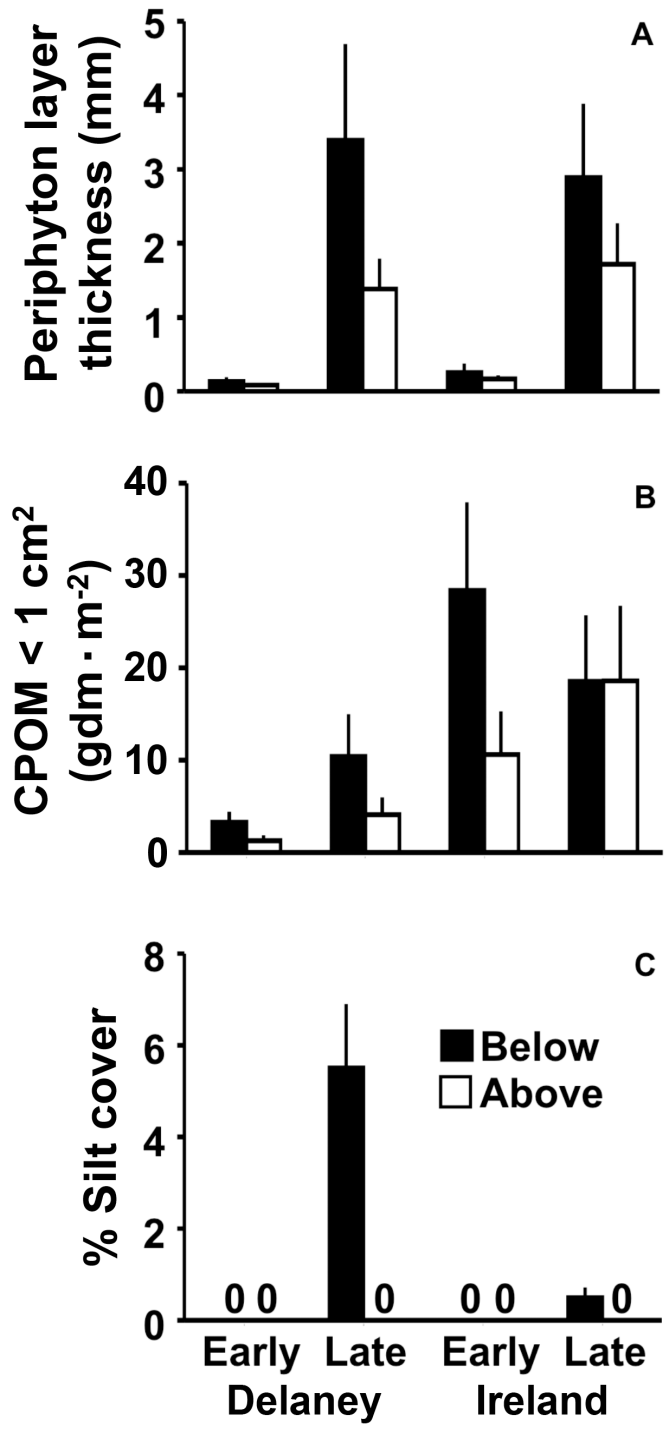

Fig. 1. Means (SE) for habitat response variables below and above 2 stream fords (Delaney, Ireland) during early and late season (years averaged): (A) Periphyton thickness on substrata; significant contrasts from general linear models: Treatment, Season (see also Table 1). (B) Gram dry mass per square meter $\left(\mathrm{gdm} \cdot \mathrm{m}^{-2}\right)$ of coarse particulate organic matter $(\mathrm{CPOM})$ smaller than $1 \mathrm{~cm}^{2}$; significant contrasts: Treatment, Stream. (C) Percent cover by silt; significant contrasts: Treatment $\times$ Season, Treatment $\times$ Stream.

and expected number of taxa $(E(S))$, which adjusts richness as a function of abundance using rarefaction (Magurran 2004). We used the Hilsenhoff biotic index (HBI; Hilsenhoff 1987) to assess the relative importance of "tolerant" and "sensitive" taxa in the assemblage (i.e., those that can and cannot live, respectively, in degraded habitats). The Hilsenhoff biotic index $(\mathrm{HBI})$ is $\sum\left(n_{i} a_{i}\right) / N$, where $n_{i}=$ number of individuals in the $i^{\text {th }}$ taxon, $a_{i}=$ tolerance value $(1-10)$ assigned to that taxon, and $N=$ total number of individuals in the sample. We used the Southwest Association of Freshwater Invertebrate Taxonomists (2010) guide as our primary source of tolerance values and functional feeding group classification. We also evaluated the proportional abundance of sensitive taxa (tolerance 0-2) and tolerant taxa (tolerance 7-10; see also Herbst et al. 2012). Proportional variables were square-root transformed $\left[(y)^{0.5}+(y+1)^{0.5}\right]$, and other variables were $\log$ transformed $[\log (\mathrm{y}+1)]$, although a small number of variables met the assumption of normality of residuals (KolmogorovSmirnov test) in an untransformed state and were therefore not modified. We estimated power $a$ priori with G*Power (Erdfelder et al. 1996). Because of the potential anthropogenic effects, we determined the alpha level necessary to allow equivalent beta error and adequate power (Mapstone 1995, Erdfelder et al. 1996) (i.e., $\alpha=\beta=0.064$, with an associated power of 0.936). We present both $\alpha=0.05$ and $\alpha=0.064$ as significance thresholds to offer additional perspective (additional discussion in Holmquist et al. 2010). Rank-abundance plots were constructed as a function of Treatment and Season to complement the general linear models.

\section{Results}

Below-above ford differences were apparent for most habitat variables. There were Treatment main effects for small CPOM $(<1$ $\left.\mathrm{cm}^{2} ; P=0.0086\right)$, periphyton layer thickness $(P=0.040)$, and percent gravel cover $(P=$ 0.017 ); all were greater below fords (Fig. 1, Table 1). There were no Treatment $\times$ Season interactions for these variables. There were Treatment $\times$ Season interactions for both percent silt and sand cover, and both indicated greater below-above sediment cover differences (greater silt and sand below fords) in late season than were observed in early season (Fig. 1, Table 1). Indeed, we only detected silt in late season and below fords, and amounts were 10-fold greater in Delaney than in Ireland. There was also an accompanying Treatment main effect for silt, but it is generally 


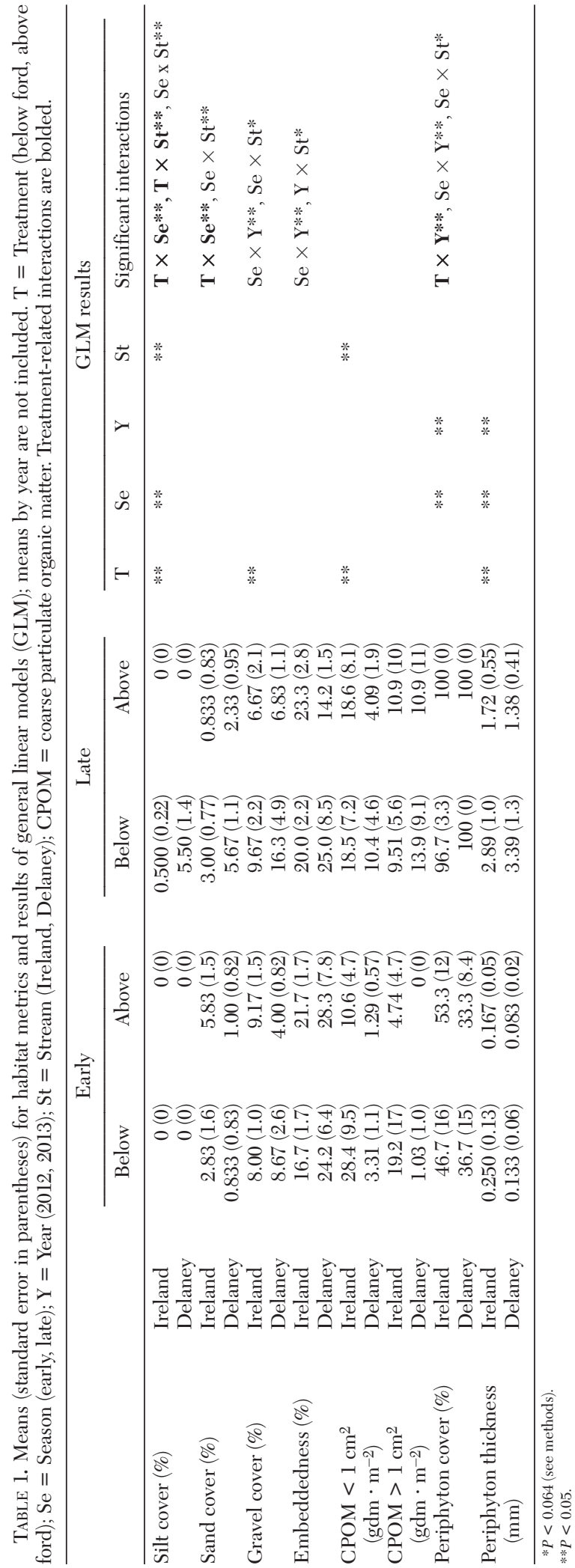





Fig. 2. Means (SE) for faunal assemblage metrics below and above 2 stream fords (Delaney, Ireland) during early and late season: (A) Total abundance $\cdot \mathrm{m}^{-2}$; significant contrasts from general linear models: Treatment, Season (see also Table 2). (B) Species richness $\cdot 0.09 \mathrm{~m}^{-2}$; significant contrasts: Treatment, Season. (C) Expected number of species; significant contrasts: Season, Treatment $\times$ Stream.

not advisable to assess main effects in the presence of related interactions (Sokal and Rohlf 2012). Periphyton cover was greater below fords in 2012 but not 2013 (Treatment $\times$ Year). There were main effect differences for Season (more silt and periphyton cover and thickness in late season), as well as some
Year and Stream effects and related interactions (Table 1).

Below-above ford differences were also present for most faunal assemblage metrics. Mean abundance and species richness were greater below fords across both early and late season $(P=0.0048$ and 0.028 , respectively); values were higher in late season (Fig. 2, Table $2)$. Conversely, $E(S)$ was lower below-ford than above (Delaney only). These trends for individual metrics are underscored by rankabundance plots (Fig. 3). Higher abundance and richness were apparent below fords, but there was also high dominance below fords. The trends of higher abundance and richness during late season were clear in the rankabundance plots as well. Percent tolerant fauna and HBI were significantly higher below fords in late season (Treatment $\times$ Season, $P=$ 0.047 and 0.017 , respectively; Table 2, Fig. 4).

The highest densities across all study factors at the order level were observed for Diptera $\left(\bar{x}=438 \mathrm{~m}^{-2}, \mathrm{SE} 101\right)$, Ephemeroptera $(\bar{x}=$ $83.1 \mathrm{~m}^{-2}$, SE 13), Plecoptera $\left(\bar{x}=58.2 \mathrm{~m}^{-2}\right.$, SE 11), Trichoptera $\left(\bar{x}=37.2 \mathrm{~m}^{-2}, \mathrm{SE} 14\right)$, and tubificid oligochaetes $\left(\bar{x}=12.5 \mathrm{~m}^{-2}, \mathrm{SE}\right.$ 8.1; Table 3). The 2 most abundant families were dipterans and included a number of the most abundant genera: chironomid midges (Microspectra, Eukiefferiella, Cricotopus, Orthocladius) and simuliid black flies (Prosimulium). Other common families and genera included heptageniid (Cinygmula), baetid (Baetis), and ameletid mayflies, perlodid (Rickera/Kogotus) and nemourid stoneflies, hydroptilid (Agraylea) and limnephilid caddisflies, and naidid oligochaetes. Diptera and Plecoptera had the highest richness of families and genera.

There were a number of trends of either higher or lower population densities below fords; tolerant taxa generally had higher abundances below fords. The speciose, abundant, and tolerant chironomid midges were more common below fords than above fords during late season (Treatment $\times$ Season, $P=0.029$ ), contributing to the trend of higher richness and abundance below fords (Fig. 4, Table 3). Two of the most abundant chironomid taxa also had Treatment-related trends: Eukiefferiella sp. 1 was similarly more abundant below fords than above fords in late season, and Cricotopus sp. was more abundant below fords at Delaney Creek only (Treatment $\times$ Stream). Baetidae (intermediate tolerance) were 


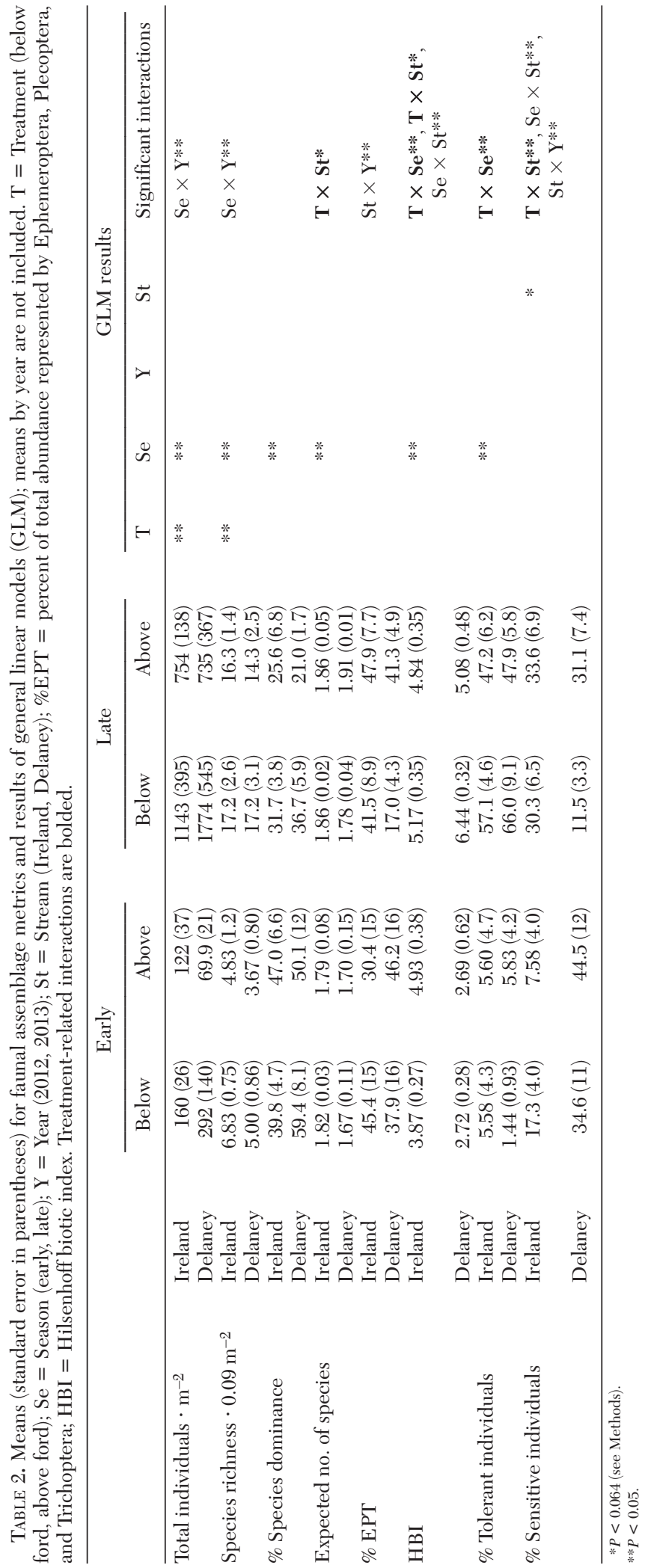




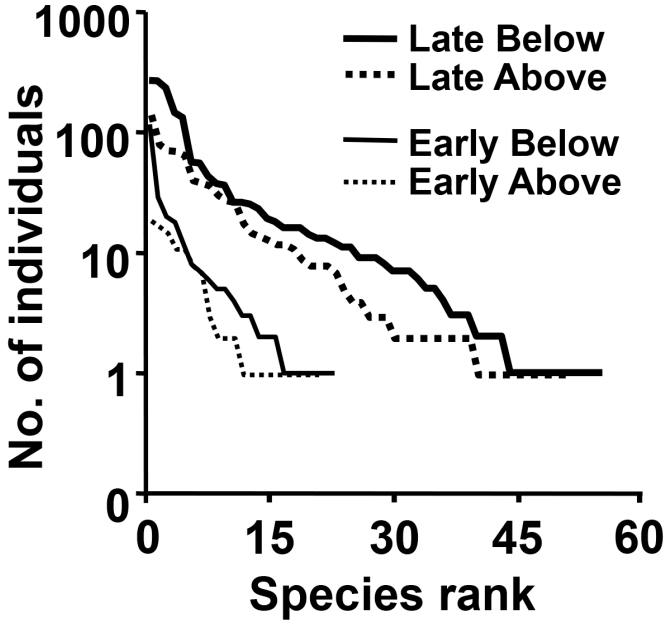

Fig. 3. Overall rank abundance plot by Treatment and Season using sample totals.

more abundant below fords than above at Delaney (Table 3). The comparatively sensitive heptageniid mayflies and nemourid stoneflies were both more abundant below fords than above fords during early season, but the inverse held during late season (Treatment $\times$ Season). Hydroptilid microcaddisflies were less abundant below fords at Delaney. Nine of the top 10 families and 8 of the 10 most abundant taxa showed significant seasonal differences. Eight of these 9 families were more abundant overall in late season, as were all 8 of the specieslevel taxa that had a Season main effect.

Below-above ford differences were present among functional feeding groups. Collectorgatherers in combination with omnivores represented $\sim 90 \%$ of the below-ford Delaney assemblage in late season (Treatment $\times$ Season, $P=0.0045$; Fig. 4, Table 4). Collector-gatherers were dominated by Baetis and the chironomids Microspectra, Cricotopus, and Orthocladius, as were omnivores by the chironomid Eukiefferiella. Percentage of predators, of which Isoperla and Rickera/Kogotus stoneflies were a dominant component, was higher below fords in early season, but was lower below the Delaney ford in late season (Table 4). Collectorfilterers, mostly simuliid black flies, showed a strong seasonal effect (higher percentage in early season) but no treatment effect. Piercerherbivores were, conversely, completely absent in early season; Season main effects were present for all groups except shredders.
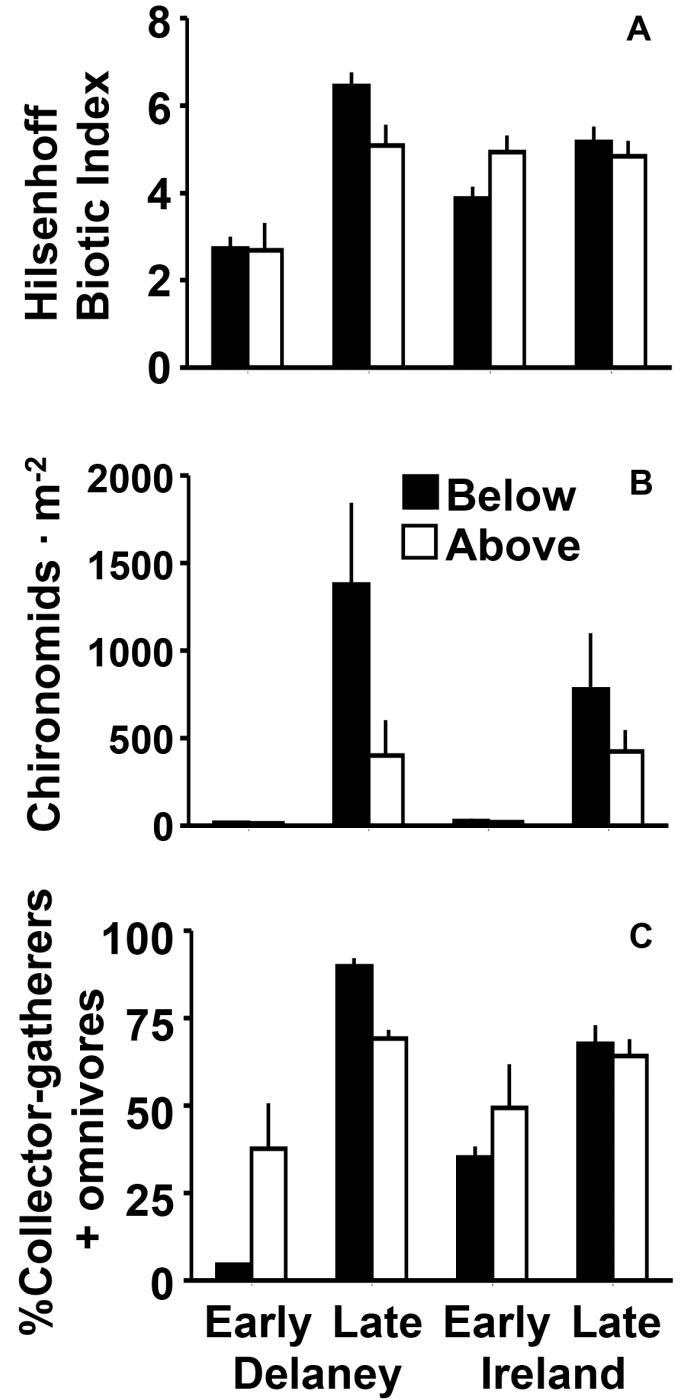

Fig. 4. Means (SE) for faunal metrics below and above 2 stream fords (Delaney, Ireland) during early and late season: (A) Hilsenhoff biotic index; higher numbers indicate greater tolerance to degraded conditions; significant contrasts from general linear models: Treatment $\times$ Season, Treatment $\times$ Stream (see also Table 2). (B) Chironomid midges $\cdot \mathrm{m}^{-2}$; significant contrasts: Treatment $\times$ Season (see also Table 3); (C) Percent collector-gatherers + omnivores; significant contrasts: Stream, Treatment $\times$ Season (see also Table 4).

\section{Discussion}

This study examined only 2 fords, thus requiring caution in interpretation, but results suggest some effects immediately downstream of crossings. Below-above differences that were 


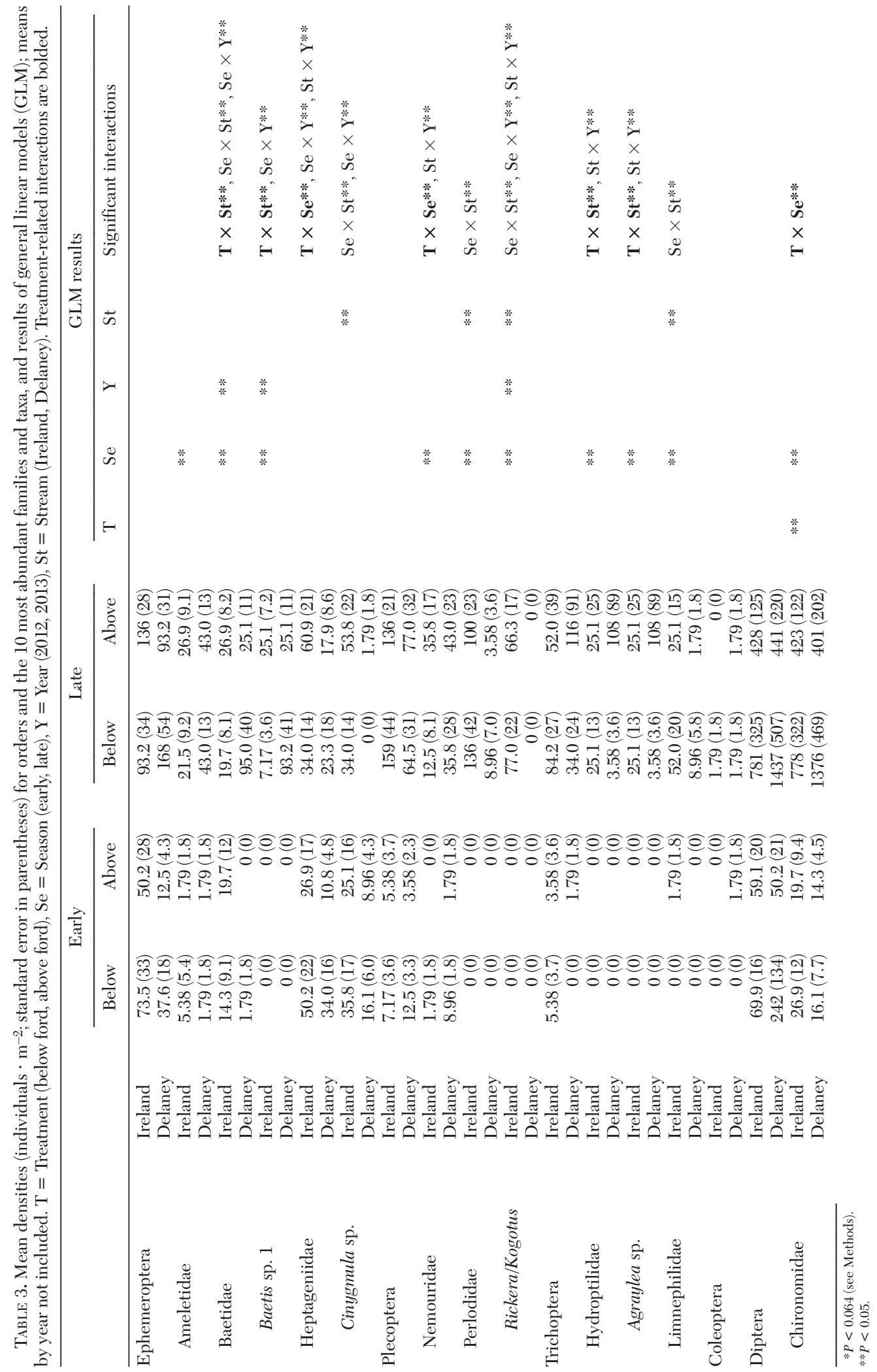




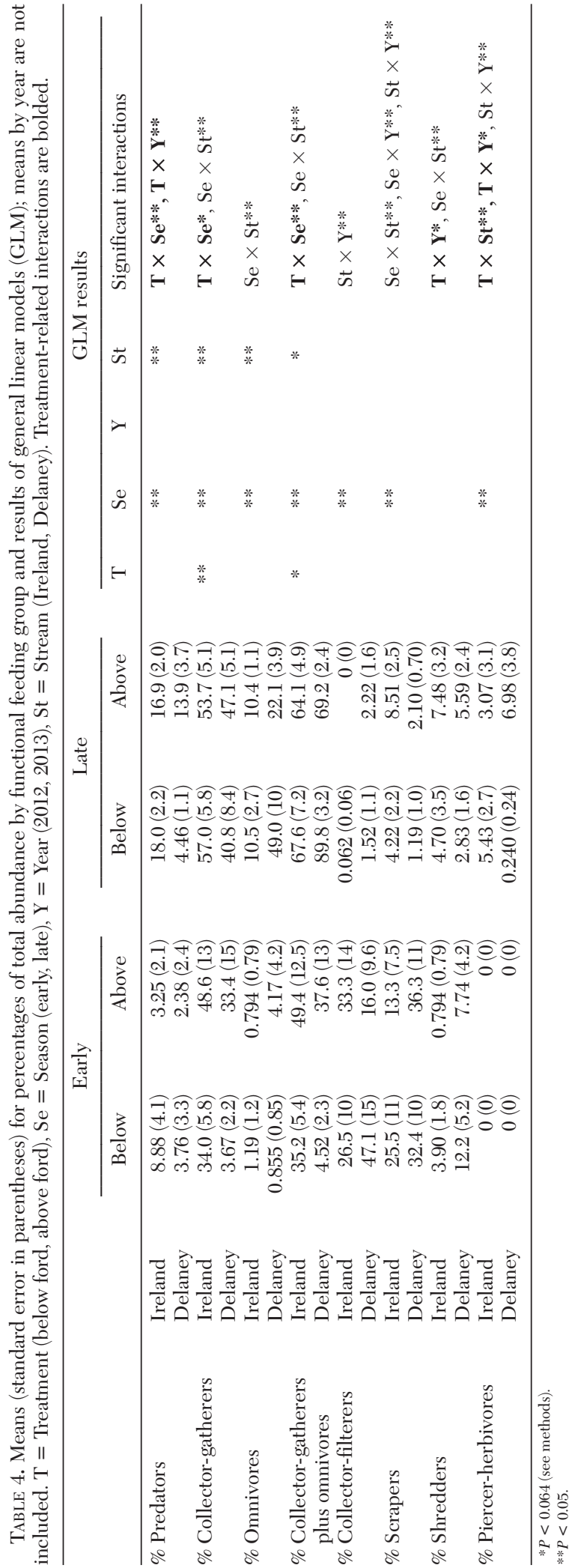


already present before most annual use may indicate longer-lasting effects (see also Holmquist et al. 2010, 2013) that persist through winter and snowmelt flooding. Other belowabove differences appeared only in late season. Summer use, perhaps compounded by low flows (Fritz et al. 1999), may have affected these measures, but lack of trail activity and periphyton dieback during winter, along with spring flushing flows, may have facilitated annual recovery (Fritz et al. 1999, Braccia and Voshell 2007, see also Gard 2002) such that early season differences were not present. Some late-season responses might also be indicative of longer-term impacts that only became detectable with population increases during late summer (see also Holmquist et al. 2013). The Delaney-only effects are consistent with the stream's more frequent crossings and shorter interdisturbance interval, although other unknown, interstream differences could have been influences as well.

Both stock and hikers probably contributed to the apparent habitat differences that were observed. Trail soil is loosened both by hikers and stock and transported downslope during rainfall along trail approaches to fords (Newsome et al. 2004, see also Kidd et al. 2014). Equine use promotes sediment yields that are 2-8 times greater than those produced by hikers (Kidd et al. 2014), but there were more hikers than stock, and total sediment yield from hikers could have equaled or surpassed yield from stock. Stock may have had a stronger influence on other apparent effects. We observed silt, sand, gravel, and small CPOM (see also Mathooko 2001) being directly mobilized at fords during stock crossings. In contrast, hiker mobilization of materials at fords was essentially absent because hikers were observed to always use logs or rocks to cross the streams. We observed deposits of hay fragments in pools below the Delaney ford that were identical in size and shape to those in local equine feces, suggesting direct feces input by stock and/or transport of pulverized feces from the trail approaches. Direct feces and urine input from hikers was likely low to absent, particularly because these sites are close enough to trailheads that there is little or no camping at these locations. Older stock fecal material settled at fords may be resuspended by subsequent crossings (Miller et al. 2010) and transported below fords. The trends of increased sediment, CPOM, and periphyton immediately downstream of fords align with studies of more spatially extensive use of streams by livestock (Braccia and Voshell 2007, Herbst et al. 2012). Our observed belowabove differences for fines were greater than Fritz et al. (1999) found at bison fords.

Below-above faunal differences may have been indirectly mediated by possible changes to the physical environment and trophic resources (Braccia and Voshell 2007, Herbst et al. 2012). Increases in fine sediment reduce interstitial volume and reduce habitat quality on upper substrate surfaces, leading to decreases in sensitive taxa and increases in abundance for oligochaetes and many chironomid taxa (Braccia and Voshell 2007, Kidd et al. 2014). Increased periphyton is often accompanied by increases in total faunal abundance, driven by increases in abundances of tolerant taxa (Tonkin et al. 2013). Faunal responses were similarly broadly consistent with responses to more extensive livestock use (Braccia and Voshell 2007, Herbst et al. 2012), and apparent faunal responses were also greater than those observed immediately below bison fords (Fritz et al. 1999). Below-above differences for fauna in our study tended to be greatest in late season, in concert with the greatest observed habitat differences.

We did not address how far downstream below-above differences may extend, as all of our sites were within $80 \mathrm{~m}$ of the fords. Manure can be carried $50 \mathrm{~m}$ downstream from the deposition point (Miller et al. 2010), and effects might be found further downstream.

Our results should be at least partially applicable to stock crossings that are not associated with formal fords where trails cross streams. Free-ranging domestic cattle focus crossings at specific points along streams, even when there is free access to an entire stream reach or segment (Clark 1998). Concentrated crossings and attendant effects may thus occur in other scenarios as well.

Bridges are physical interventions that prevent direct stream disturbance but may still allow drainage of sediment and feces into streams during rains (Newsome et al. 2004). Such structures are expensive and difficult to construct in remote wilderness areas. Minimization of trail slope angle near fords is less expensive and can reduce sedimentation from both hikers and stock (Marion and Leung 
2004, Olive and Marion 2009, Kidd et al. 2014). Unlike free-ranging livestock, pack stock come with riders, and equine behavior may facilitate simple interventions that could reduce the effects attributable to stock. Equines can only urinate when stationary, and standing in water and urination by nearby animals are urination stimuli (pack stock handlers, personal communication). Briefly halting stock strings before reaching fords should reduce the volume of urine and feces directly entering streams (see also Billings 2005). Additionally, strings can be moved quickly across fords if watering is not needed. These approaches entail no expense and require only the cooperation of stock handlers.

\section{ACKNOWLEDGMENTS}

Marie French, Rick Dodson, Tom Francis, and Marianne Gengenbach provided laboratory and/or field assistance. We thank Dannique Aalbu, Dave Clow, Mark Fincher, Harrison Forrester, Victoria Hartman, Dave Herbst, Dave Kari, Tim Kuhn, Linda Mazzu, Todd Newburger, and Bob Westfall for background information, project assistance, and/or discussion. Steve Fend identified representative oligochaetes. The administration and staff of White Mountain Research Center provided excellent support throughout the project. Research was funded by Yosemite National Park (National Park Service P12AC15022) with expert facilitation by Angela Evenden of the Californian Cooperative Ecosystems Studies Unit and built upon earlier NPSfunded work (J8R07090011 and J8C07100012).

\section{Literature Cited}

Allan, J.D., AND M.M. Castillo. 2007. Stream ecology: structure and function of running waters. 2nd edition. Springer, Netherlands. 436 pp. dx.doi.org/10.1007/ 978-1-4020-5583-6

BiLlings, T.M. 2005. Equestrian knowledge of environmental impacts on trails. Master's thesis, Oklahoma State University, Stillwater, OK.

Braccia, A., and J.R. Voshell, Jr. 2007. Benthic macroinvertebrate responses to increasing levels of cattle grazing in Blue Ridge Mountain streams, Virginia, USA. Environmental Monitoring and Assessment 131:185-200.

CLARK, E.A. 1998. Landscape variables affecting livestock impacts on water quality in the humid temperate zone. Canadian Journal of Plant Science 78:181-190.

Cole, D.N. 1995. Experimental trampling of vegetation. I. Relationship between trampling intensity and vegetation response. Journal of Applied Ecology 32:203-214.
Cole, D.N., J.W. van Wagtendonk, M.P. McClaran, P.E. MoORe, and N.K. McDougald. 2004. Response of mountain meadows to grazing by recreational pack stock. Journal of Range Management 57:153-160.

Deluca, T.H., W.A. Patterson IV, W.A. Freimund, and D.N. CoLE. 1998. Influence of llamas, horses, and hikers on soil erosion from established recreation trails in western Montana, USA. Environmental Management 22:255-262.

Derlet, R.W., AND J.R. CARLSON. 2006. Coliform bacteria in Sierra Nevada wilderness lakes and streams: what is the impact of backpackers, pack animals, and cattle? Wilderness and Environmental Medicine 17:15-20.

Erdfelder, E., F. Faul, and A. Buchner. 1996. GPOWER: a general power analysis program. Behavioral Research Methods, Instruments, and Computers 28:1-11.

FritZ, K.M., W.K. Dodds, and J. Pontius. 1999. The effects of bison crossings on the macroinvertebrate community in a tallgrass prairie stream. American Midland Naturalist 141:253-265.

GARD, M.F. 2002. Effects of sediment loads on the fish and invertebrates of a Sierra Nevada river, California. Journal of Aquatic Ecosystem Stress and Recovery 9:227-238.

Hauer, F.R., AND V.H. Resh. 2007. Macroinvertebrates. Pages 435-463 in F.R. Hauer and G.A. Lamberti, editors, Methods in stream ecology. 2nd edition. Academic Press, San Diego, CA. dx.doi.org/10.1016/ B978-012332908-0.50028-0

Herbst, D.B., M.T. Bogan, S.K. Roll, and H.D. SaFFord. 2012. Effects of livestock exclusion on in-stream habitat and benthic invertebrate assemblages in montane streams. Freshwater Biology 57:204-217.

HiLsenhoff, W. 1987. An improved biotic index of organic stream pollution. Great Lakes Entomologist 20:31-39.

Holmquist, J.G., J. Schmidt-Gengenbach, and E.A. BALLENGER. 2014. Patch-scale effects of equine disturbance on arthropod assemblages and vegetation structure in subalpine wetlands. Environmental Management 53:1109-1118.

Holmquist, J.G., J. Schmidt-Gengenbach, and S.A. Haultain. 2010. Does long-term grazing by pack stock in subalpine wet meadows result in lasting effects on arthropod assemblages? Wetlands 30:252-262.

Holmquist, J.G., J. Schmidt-Gengenbach, and S.A. Haultain. 2013. Effects of a long-term disturbance on arthropods and vegetation in subalpine wetlands: manifestations of pack stock grazing in early versus mid-season. PLOS ONE 8:e54109.

Holmquist, J.G., and T.J. Waddle. 2013. Predicted macroinvertebrate response to water diversion from a montane stream using two-dimensional hydrodynamic models and zero flow approximation. Ecological Indicators 28:115-124.

KidD, K.R., W.M. Aust, and C.A. Copenheaver. 2014. Recreational stream crossing effects on sediment delivery and macroinvertebrates in southwestern Virginia, USA. Environmental Management 54: 505-516.

MagurRan, A.E. 2004. Measuring biological diversity. Blackwell, Malden, MA. 264 pp.

Mapstone, B.D. 1995. Scalable decision rules for environmental impact studies: effect size, type I, and type II errors. Ecological Applications 5:401-410.

Marion, J.L., AND Y.-F. LEUng. 2004. Environmentally sustainable trail management. Pages 229-258 in 
R. Buckley, editor, Environmental impacts of ecotourism. CABI Publishing, Wallingford, United Kingdom. dx.doi.org/10.1079/9780851998107.0229

Матнооко, J.M. 2001. Disturbance of a Kenya Rift Valley stream by the daily activities of local people and their livestock. Hydrobiologia 458:131-139.

MCClaran, M.P. 1989. Recreational pack stock management in Sequoia and Kings Canyon National Parks. Rangelands 11:3-8.

McIver, J.D., And M.L. McInNIS. 2007. Cattle grazing effects on macroinvertebrates in an Oregon mountain stream. Rangeland Ecology and Management 60:293-303.

Miller, J., D. Chanasyk, T. Curtis, T. Entz, and W. WILLMS. 2010. Influence of streambank fencing with a cattle crossing on riparian health and water quality of the Lower Little Bow River in Southern Alberta, Canada. Agricultural Water Management 97:247-258.

Moore, P.E., J.W. van Wagtendonk, J.L. Yee, M.P. McClaran, D.N. Cole, N.K. MCDougald, and M.L. BRoоKs. 2013. Net primary productivity of subalpine meadows in Yosemite National Park in relation to climate variability. Western North American Naturalist 73:409-418.

Newsome, D., D.N. Cole, and J.L. Marion. 2004. Environmental impacts associated with recreational horse-riding. Pages 61-82 in R. Buckley, editor, Environmental impacts of ecotourism. CABI Publishing, Wallingford, United Kingdom. dx.doi.org/ 10.1079/9780851998107.0061

Olive, N.D., and J.L. Marion. 2009. The influence of use-related, environmental, and managerial factors on soil loss from recreational trails. Journal of Environmental Management 90:1483-1493.

Ostoja, S.M., M.L. Brooks, P.E. Moore, E.L. Berlow, R. Blank, J. Roche, J. Chase, and S. Haultain. 2014. Potential environmental effects of pack stock on meadow ecosystems of the Sierra Nevada, USA. Rangeland Journal 36:411-427.

Pickering, C.M., W. Hill, D. Newsome, and Y.-F LEUNG. 2010. Comparing hiking, mountain biking and horse riding impacts on vegetation and soils in Australia and the United States of America. Journal of Environmental Management 91:551-562.

SOKaL, R.R., AND F.J. RohlF. 2012. Biometry. 4th edition. W.H. Freeman and Co., New York, NY.

Southwest Association of Freshwater Invertebrate TAXONOMISTS. 2010. List of tolerance values and functional feeding groups. http://safit.org/TVFFG.html

Stevenson, R.J., and S.L. Rollins. 2007. Ecological assessments with benthic algae. Pages 785-803 in F.R. Hauer and G.A. Lamberti, editors, Methods in stream ecology. 2nd edition. Academic Press, San Diego, CA. dx.doi.org/10.1016/B978-012332908-0.50047-4

Stoddard, J.L., D.P. LARSEN, C.P. HaWkins, R.K. Johnson, AND R.H. NORRIS. 2006. Setting expectations for the ecological condition of streams: the concept of reference condition. Ecological Applications 16:1267-1276.

SYSTAT. 2007. SYSTAT 12. SYSTAT Software, Inc., San Jose, CA.

Tonkin, J.D., R.G. Death, and K.J. Collier. 2013. Do productivity and disturbance interact to modulate macroinvertebrate diversity in streams? Hydrobiologia 701:159-172.

Törn, A., A. Tolvanen, Y. Norokorpi, R. Tervo, and P. SIIKAMÄKI. 2009. Comparing the impacts of hiking, skiing and horse riding on trail and vegetation in different types of forest. Journal of Environmental Management 90:1427-1434

WADDLE, T.J., AND J.G. HoLMQUIST. 2013. Macroinvertebrate response to flow changes in a subalpine stream: predictions from two-dimensional hydrodynamic models. River Research and Applications 29:366-379. dx.doi.org/10.1002/rra.1607.

Wilson, J.P., AND J.P. SENEy. 1994. Erosional impact of hikers, horses, motorcycles, and off-road bicycles on mountain trails in Montana. Mountain Research and Development 14:77-88.

Received 6 November 2014 Accepted 7 April 2015

APPENDIX. Means (standard error in parentheses) for physical parameters above and below fords. Gravel, sand, and silt results are in Fig. 1 and Table 1.

\begin{tabular}{lcc}
\hline Physical parameter & Below ford & Above ford \\
\hline Distance from ford $(\mathrm{m})$ & $31.5(13)$ & $39.1(14)$ \\
Wetted width $(\mathrm{m})$ & $4.6(0.27)$ & $4.4(0.25)$ \\
Velocity $\left(\mathrm{cm} \cdot \mathrm{s}^{-1}\right)$ & $33.9(4.3)$ & $35.4(4.7)$ \\
Water depth $(\mathrm{cm})$ & $12.7(1.5)$ & $14.1(1.6)$ \\
Water temperature $\left({ }^{\circ} \mathrm{C}\right)$ & $10.6(0.35)$ & $11.5(0.42)$ \\
pH & $6.8(0.07)$ & $6.9(0.05)$ \\
$\%$ Bedrock & $1.3(1.3)$ & $0.0(0.0)$ \\
$\%$ Boulder $(>256 \mathrm{~mm})$ & $1.3(1.3)$ & $1.0(0.85)$ \\
$\%$ Cobble $(64-256 \mathrm{~mm})$ & $69.0(3.7)$ & $77.3(2.8)$ \\
\% Pebble $(16-64 \mathrm{~mm})$ & $14.1(1.8)$ & $12.9(2.0)$ \\
\hline
\end{tabular}

